\title{
Recent changes to immigration laws: Implications for hospitality employers
}

\section{Stewart Dalley}

Stewart is a Senior Solicitor with Ryken and Associates

(www.rykenlaw.co.nz). He assists in all aspects of immigration and refugee law, including advising on visas, deportation and humanitarian claims. He has experience in representing clients at the Immigration and Protection Tribunal, Family Court, District Court and High Court.

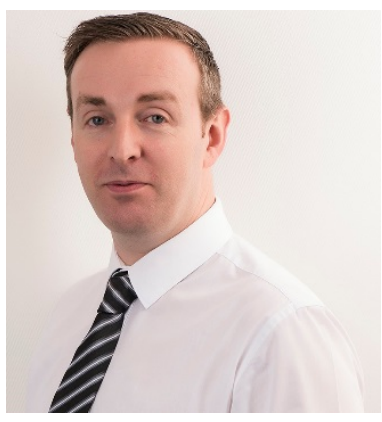

Stewart is an active member of the Auckland District Law Society's Immigration and Refugee Law Committee, where he engages with Immigration New Zealand, the Immigration Protection Tribunal, and other
Immigration New Zealand (INZ) recently announced changes to the skilled migrant residence and essential-skills work visas based on a strong association between skills and salary. This shift will impact both employers and migrants, especially in hospitality.

According to the INZ, the hospitality sector was the fourth-largest recipient of skilled migrant residence visas in their last reporting year [1,2]. INZ expects migrants employed as chefs, café/restaurant managers and retail managers to be the hardest hit by these changes [1,2]. Residence under the skilled migrant policy can be gained for jobs in skill levels 1-3 as defined in the Australian and New Zealand Standard Classification of Occupations (ANZSCO). Traditionally, hotel managers, chefs, and café/restaurant managers have been classed as level 2, and bakers at level 3 in accordance with ANZSCO. However, skills levels are now also assessed based on salary (at least \$23.49 $\mathrm{p} / \mathrm{h}$ ) and specialist skills obtained through qualifications and/or work experience.

Migrants paid a justifiable $\$ 35.24 \mathrm{p} / \mathrm{h}$ for a position previously considered unskilled (levels 4-5), or those with positions unclassified by ANZSCO, could gain residence under the new policy shift. While this could mean a residence visa for people whose jobs do not neatly fit within ANZSCO, INZ are not easily deceived. Indeed, the Labour Inspectorate reports that 20 percent of the published list of employers currently barred from recruiting migrants (due to breaches of employment and immigration laws) are in the hospitality sector. Accordingly, there is little to be gained by migrants claiming to be paid $\$ 80,000$ for a housekeeping position.

Approximately 21 percent of essential-skills work visas issued by Immigration New Zealand in the last reporting year were for migrants in the hospitality sector [1,2]. Essential-skills work visas cover five skills levels (as indicated by ANZSCO) but now have accompanying salary thresholds. The main change affects migrants earning below $\$ 19.97 \mathrm{p} / \mathrm{h}$ because they will now be unable to sponsor their partner's work visa or child's domestic student visa. While their partner and child would still be able to apply for visas, the partner would have to meet the visa requirements in their own right to obtain a work visa, and their child could only obtain an international student visa - the costs associated with which would likely consume the 'low' salary of the migrant worker. Additionally, this 'low-skilled' migrant will only be able to obtain one 'lowskilled' essential-skills work visa of three-year duration before experiencing a 12-month stand-down period, during which they would be barred from applying for another 
outside organisations, to help shape and inform discussion on immigration and refugee-related policy matters. His work has been published in the New Zealand Law Society's official magazine (LawTalk) and the New Zealand Law Journal. low-skilled essential-skills work visa. This does not, however, prevent the migrant from applying for an essential-skills visa at a higher skill level or for a visa in another category entirely. Those in positions assessed as skill levels $4-5$ under ANZSCO and paid below $\$ 19.97 \mathrm{p} / \mathrm{h}$ will only be issued a 12 -month work visa, and will be unable to sponsor a partner for a work visa or a child for domestic student status. There are some elements of the policy change that are not retrospective. It is, therefore, vital to seek specific advice in each case.

Many employers will now be faced with the prospect of increasing salaries to attract migrants or expending more time and resources to recruit and train New Zealanders. However, it is recalled that many employers, particularly in the regions, have experienced recruitment difficulties for decades. It is, therefore, unclear whether these changes will produce the desired increase in job opportunities and salaries for New Zealanders or whether they will only add to the recruitment woes of employers.

\section{Corresponding author}

Stewart Dalley can be contacted at: stewart@rykenlaw.co.nz

\section{References}

(1) New Zealand Immigration. www.immigration.govt.nz/about-us/research-andstatistics/statistics

(2) Ministry of Business, Innovation and Employment. Aide Memoire Information for Ministers: Composition of the Skilled Migrant Category - updated slide pack, May 26, 2016. 